\title{
Information technology reliability influence on controlling excellence
}

Agnieszka Bieńkowska. Wrocław University of Science and Technology. Poland agnieszka.bienkowska@pwr.edu.pl

Katarzyna Tworek. Wrocław University of Science and Technology. Poland katarzyna.tworek@pwr.edu.pl

Anna Zabłocka-Kluczka. Wrocław University of Science and Technology. Poland anna.zablocka-kluczka@pwr.edu.pl

\begin{abstract}
Controlling solutions implemented in the organization evolve in a continuous manner. They are becoming more "mature" - expanding the scope and depth of implemented solutions in striving for excellence. Nowadays, meeting controlling demands (in case of information requirements) is impossible without information technology (IT) support. Hence, IT reliability seems to play a special role in this maturation process. The notion of IT reliability is discussed in the paper as a prerequisite for the implementation of this management support method. Potential factor favoring the process of maturation of controlling solutions are also discussed. The aim of the paper is to identify what is the influence of IT reliability on controlling maturity (and excellence). The analysis will cover relations between the time of use of controlling (as an expression of maturity and excellence), the quality of its outputs, the results obtained due to its implementation in the organization and IT reliability, considered as a moderator of changes in controlling in the organization. The proposed theoretical framework is verified empirically on the sample of 557 organizations operating in Poland.
\end{abstract}

Keywords: management, controlling excellence, controlling maturity, IT reliability

DOI: 10.4192/1577-8517-v19_1

Submitted June 2018 Accepted November 2018 


\section{INTRODUCTION}

Controlling, as one of the most often used methods of management in contemporary organization (Bieńkowska and Zgrzywa-Ziemak, 2011), is understood as "a method of management support used mainly in the areas of planning, controlling and steering - for the implementation of functions such as information supply, coordination, supervision, monitoring or participation in management; enabling managers - through its measurable and economical overtone - for making rational (and apt) decisions, and thus aimed at achieving the goals of the organization as a whole" (Bieńkowska, 2015). Controlling solutions implemented in the organization change over time, evolving in a continuous manner. It makes this method more and more perfect and enables the organization to gain more and more benefits from its use.

The controlling implementation process starts with the determination of scope and complexity of changes and the way they are introduced in the organization. Interestingly, the designed solutions are never excellent in the absolute sense (excellence is understood as the ideal, perfection), but they are considered excellent in the context of specific characteristics of the organization and the existing conditions of its functioning (excellent i.e. complete, fulfilling its purpose and functions, to which they are intended). The implementation of controlling is considered to be a long-lasting process (Sierpińska and Niedbała, 2003), however limited to a certain time frame. It is dependent on the degree of preparation for the implementation (pre-conditions for controlling implementation), complexity of implemented solutions, and the level of employees' competence in the area of controlling, but always limited by certain time frame.

After the implementation stage, the process of early functioning of the controlling starts, during which the stabilization of controlling solutions occurs, as well as its full adaptation (embedding) in the organization. Nowosielski (2001) writes about the "necessary evolutionary change in economic awareness and mentality of the management and employees of individual entities", which takes place during this stage, causing the increase of competences of both controllers and controlling managers. Thus, the conditions for the controlling functioning are changed. The proficiency in using controlling solutions and understanding its essence (both growing in time) are conducive to searching for more and better ways to implement the functions and tasks of controlling and - as a result - are a 
manifestation of its everyday improvement. Although they are not always associated with any noticeable, spectacular changes in the field of controlling solutions, they usually cause an increase in the results of its functioning in the organization.

As time goes by and changes in the internal and external conditions of the organization functioning occur (changes in size or configuration of organization, IT development, emergence of new markets, etc.), existing controlling solutions must be improved, otherwise they will lose the ability to perform the functions for which they were created (they will cease to be excellent under given conditions), and the organization will cease to benefit from the implementation of controlling.

Therefore, considering all the above, it is not surprising that the controlling time of use in organization is often perceived as a feature of its maturity and excellence (Nowosielski, 2011; Chachuła, 2009; Goto et al., 2014). Hence, it can be assumed that the time of controlling functioning in the organization is the simplest indicator of the maturity and excellence of controlling. Of course, it does not determine the shape of controlling solutions, but it is assumed to be one of the factors differentiating these solutions.

It seems that instrumental solutions connected with information technology (IT) tools supporting controlling are of particular importance in the process of its implementation and improvement. The appropriate design of IT solutions and adaptation to the needs of controlling is a prerequisite for the implementation of this management support method. Lira et al. (2012) underline that alignment between IT and controlling requirements is especially needed in order to maximize the results obtained by the organization from using this particular management method. That is mainly because nowadays, meeting controlling demands (in case of information requirements) is impossible without IT support (Peleias and Parisi, 2001; Lira et al., 2012), as well as its efficient functioning and continues improvement. In particular, the reliability of IT seems to be important (among others, as a factor influencing the before mentioned alignment), and according to the authors - it determines the achievement of high quality of controlling outputs and results obtained due to its implementation in the organization. In this context, the aim of the article will be to identify what is the IT reliability influence on controlling maturity and excellence. The analysis will consider relations between the time of use (as an expression of maturity and 
excellence) of controlling, the quality of its outputs, the results obtained due to its implementation in the organization and IT reliability, considered as a moderator of changes in controlling in the organization. However, the first step is to define the notions of controlling maturity and excellence related to the time of its use in the organization.

\section{CHANGES IN CONTROLLING OVER TIME - EXCELLENCE AND MATURITY OF CONTROLLING}

The issue of changes made within individual, modern methods of management is current and important both in theory and in business practice. The essence of the changes should be seen in perfecting the solutions and improving the efficiency of the given method (i.e. striving for the excellence of the method, undoubtedly a manifestation of its maturity). That is to gain even greater results from its implementation.

The maturity and excellence of controlling is discussed in the literature (Nowosielski, 2013), as features associated with the changes of this method over time. In general terms, maturity and excellence are synonymous in the literature in reference to controlling, often used interchangeably, although the concept of excellence seems to be more semantically complex (Figure 1).

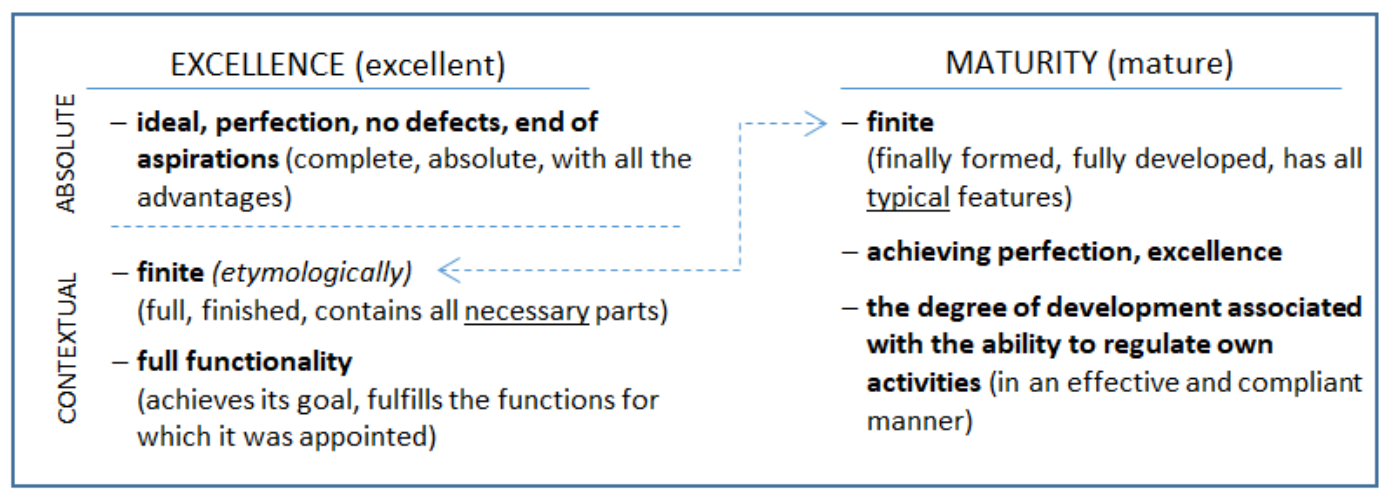

Figure 1. Semantic complexity of concepts: excellence, maturity

By analogy to the field of philosophy, where excellence is considered on two levels: metaphysical (excellence is not gradable and is not comparable with anything else) and practical (associated with human actions) (Konstańczak 2016), excellence can be discussed in two meanings: absolute and contextual. In the absolute sense, it is considered as the best of all, an ideal that marks the end of 
aspirations and, at the same time, the lack of opportunity for improvement, because the excellent thing cannot be improved (according to its meaning). Excellence can be understood as something that fulfills the proper functions, or something that achieves the goal (Konstańczak, 2016). Referring to the theory of situational conditions, in the field of management there are solutions that are excellent in a given conditions. Moreover, along with changing conditions, those solutions can be further improved in pursuit of an ideal, which was previously impossible to achieve.

In the field of management, maturity and excellence usually refer to the organization, or part of it, but also to management support methods. In this paper and with regard to controlling, it was assumed that mature controlling is a method, which on the one hand meets the requirements set for it (at least at the minimal acceptable level), and on the other hand is able to strive for excellence, adapting to the environment and characteristics of the organization itself. Excellent controlling is a method contextually excellent, understood as model solution, which - in accordance with the theory of situational conditions - is fully adapted to both the characteristics of the organization and the conditions of the environment, in which the organization operates (Bieńkowska, 2015). With regard to controlling, the absolute excellence is impossible. Moreover, maturity and excellence are both contextually conditioned and are inseparably connected with the assessment.

The authoritative model of controlling maturity, in which further levels of organizational advancement of controlling are proposed, with the highest level being the desired (target) level is presented by Nowosielski (2013). He assumes that "from the moment of the first start up to the full usefulness of the concept of controlling there is a long road, during which many modifications and even reductions of some solutions are necessary. It is not possible for the organization to reach the highest level of development in this area immediately" (Nowosielski, 2013). It seems that the Nowosielski model refers mainly to the process of implementing controlling in the organization. This is also confirmed by the observations of Sierpińska and Niedbała (2003), who wrote about the "gradual" and so-called "full implementation" of controlling, which according to them requires tremendous consistency and determination in testing solutions, their improvement and improvement of the principles and conditions of cooperation 
between responsibility centers, the controlling unit and other organizational units of the board. Only controlling, which underwent the "full implementation" process, can be considered as a method that effectively achieves the goals set for it. Then, it will be considered as a mature controlling in a given context (solutions are acceptable and fully formed) and should be an excellent controlling in contextual characteristics. However, this excellence is not always possible, for various reasons.

Thus, the level of maturity and striving for the excellence of controlling during the process of its implementation in the organization, are basically unambiguous concepts. However, the question arises: what happens to controlling "after achieving full implementation" regardless of the time it took? It cannot be denied that the changes in controlling system occur, so what does this mean for the excellence of controlling achieved earlier? (Bieńkowska, 2015). Bender (2008) excludes the functioning of once implemented controlling in a rigid, unchanged form. As noted by Skrzyniarz (2002) a prerequisite for effective implementation and functioning of the controlling system is a dynamic approach. Assuming that controlling excellence is contextual, it should be underlined that controlling cannot freeze after implementation, but according to contextual changes, it will start to change in an evolutionary (or if necessary even in revolutionary) way. The competences and experience of both controllers and controlling managers are increasing. The controlling processes and organizational routines in this field are becoming more stable. The organization (managers) learns to use the support offered by controlling. The external conditions of the organization functioning may change as well. With the passage of time and the change of conditions, controlling achieves successive levels of excellence, meeting (in a better way) the needs and expectations of the organization as a whole.

Considering all the above, the time of controlling use in the organization can be used as the simplest indicator informing on both the maturity and excellence of controlling, i.e. the indicator influencing the increase of results obtained due to controlling implementation. Hence, the following hypotheses can be formulated:

- H1a: The longer the controlling time of use in organization, the higher the quality of controlling outputs.

- H1b: The higher is the quality of controlling outputs, the greater the results obtained due to controlling implementation. 
- H1c: The longer the controlling time of use, the greater the results obtained due to controlling implementation.

\section{RELIABLE IT AS A PRE-CONDITION FOR EFFICIENT CONTROLLING USE IN ORGANIZATION}

\subsection{IT reliability}

Reliability of IT in organization is understood as measurable property of IT, useful for its control and management, identifying its quality level and pointing out potential problems (Zahedi, 1987) and it is directly linked to the efficiency of IT components, especially those critical to its proper operations. Therefore, it can be said that IT reliability in organization is a notion build by factors connected to 3 different IT theories. First one is DeLone and McLean success model (DeLone and McLean, 2003), second one is Lyytinen (1987) 4 types of IT failure and third one is TAM model (Davis, 1985). Therefore, in order to fully develop the notion of IT reliability it was crucial to identify factors that are constructs for each of 4 identified variables proposed in the IT reliability model. To identify all of them, the search of articles published from 2000 to 2018 with EBSCO and ProQuest databases. From all available publications, those concerning lists of factors describing IT in organization were purposefully selected. Based on those research (Niu et al., 2013; Palmius, 2007; Irani, 2002), all factors potentially related to IT reliability in the context of above-mentioned 3 IT theories were identified and assigned to proposed 4 variables (Niu et al., 2013). Model of IT reliability in organization has been developed, detailed description is published by Tworek (2018a, 2018b). It was also verified in various business contexts (Tworek, 2018a, 2018b). The reliability of IT in organization consists of 4 factors: reliability of information included in IT in organization, reliability of support services offered for IS in the organization and reliability of system itself, which also includes the usability of this system.

\subsection{IT reliability as a pre-condition for controlling implementation}

According to Vollmuth (2000), before the controlling is implemented in organization, the variety of pre-conditions must be met. They can be understood as prerequisites (as opposed to secondary conditions referring to the correct shape of controlling solutions). Their fulfillment determines the correct procedure of controlling implementation, and then contributes to its effective functioning in the 
organization (Bieńkowska, 2015). The basic pre-conditions for the implementation of controlling in an organization are:

- obtaining the real approval of the top management regarding the implementation of the discussed method of management support;

- implementing the proper management style and supporting it with appropriate management techniques and principles;

- modifying the organizational structure in terms of future needs and requirements of controlling, including a clear definition and delimitation of duties, rights and responsibilities of individual positions in the organization;

- $\quad$ preparing characteristics (sheets) of workplaces;

transforming the accounting in order for it to be useful from the point of view of controlling (Vollmuth, 2000).

However, there is no doubt that above-mentioned set should be amended by the implementation of appropriate IT solutions in the organization. Fulfilling the indicated package of initial prerequisites determines efficient implementation and subsequent effective functioning of controlling. Among all the above, there are conditions (e.g., implementation of an appropriate, team-oriented, management style), which incorrect implementation will cause the worsening of results obtained due to controlling implementation. There are also conditions (e.g., adjusting the company's chart of accounts as part of transforming the accounting in order for it to be useful from the point of view of controlling), which absolutely must be implemented, in order to obtain any results from the implementation of controlling.

IT solutions are a part of the latter group. It is often underlined that "the implementation of controlling almost automatically connects with the implementation of the IT system" Młodkowski and Kałużny (2007), as it seems impossible to create, transform and transfer management information without appropriate IT systems (Peleias et al., 2009; Lira et al., 2012; Pare et al., 2015). IT is the factor, which completely changed the way contemporary organizations use management methods, including controlling. Those changes are mainly connected to the IT role in reshaping the information processes within and outside of the organization (Crowston, 2000; Walecka-Jankowska and Zgrzywa-Ziemak, 2006; 
Pare et al., 2015). Controlling seems to be especially sensitive for IT solutions support because of its information needs. Hence, nowadays - in the world characterized by high dynamics of economic processes and the growing demand of management for a wide range of management information necessary to make key decisions - it is difficult to imagine the implementation and functioning of controlling without proper IT solutions support. However, it is important to underline that the fact of using IT is not a factor differentiating organizations. Almost every organization, which has implemented controlling, also has IT solutions supporting that method. Hence, the new framework is needed to differentiate the IT used by various organizations and analyze its actual potential to influence various areas of organization operations, including management methods such as e.g. controlling (Hosseini et al., 2016). In this article, IT reliability model developed by Tworek (2018a, 2018b) is proposed as the framework used for the analysis of IT influence on various aspects of controlling use. In this context, it can be stated that IT reliability affects both the quality of controlling outputs and the results obtained due to controlling implementation in organization (Bieńkowska et al., 2018).

\subsection{IT reliability and controlling time of use}

Rapidly growing role of IT solutions needed for efficient and proper use of all management methods brought sudden changes in almost all of them, also in controlling. IT is generally known as a factor influencing organization's ability to effectively implement controlling solutions. However, it can be assumed that it is no longer only a precondition for using this management method. During the time of controlling use in organization, some changes occur that seem to be a source of influence on IT reliability. Hence, the two-sided relation between the controlling time of use and IT reliability needs some clarification. That is because on the one hand, reliability of IT in organization is the characteristic of IT perceived by its users (employees of the organization). Hence, the user experience and personal opinion about the IT is especially important in rating its reliability. Thus, it should be underlined that IT reliability is closely connected with the alignment between the analyzed IT solution and the user' tasks, it is designed to support (Niu et al., 2013; Pare et al., 2015). Hence, it can be concluded that the better the IT solution is tailored to support the given tasks, the more satisfied is the user and the higher is the level of the perceived IT reliability. Many authors underline that in case of 
controlling, IT solutions should be tailored according to the organization needs and continuously aligned with them in order to achieve results from using this management method (Lira et al., 2012). Hence, it can be concluded that controlling time of use has a potential relation with IT reliability through this alignment. Many IT lifecycle models underline that IT solution is becoming more adjusted to the given requirements over time and through the continuous improvements process (Kale, 2000). Therefore, the longer the controlling is used in the organization, the more time passed for the adjustment process to take place. Thus, it can be assumed that the perceived IT reliability level will increase over time because the users will benefit from the fact that IT solutions are becoming more customized to their needs and will recognize that they are more useful to them from the variety of reasons (e.g. improving user experience, information flow, support service).

Considering all the above, the following research hypothesis can be formulated:

- $\quad \mathrm{H} 2$ : There is a positive relation between IT reliability and controlling time of use.

\subsection{IT reliability as a moderator of controlling results}

Moreover, it can be assumed based on the arguments presented above, that IT reliability has the potential to moderate the influence of controlling time of use and quality of controlling outputs on results obtained due to controlling implementation. That it is mainly due to the alignment between IT solutions and controlling requirements is very hard to achieve without the high level of reliability of IT in organization. Weißenberger and Angelkort (2011) suggest that the point of view of both manager and controller are needed in order to analyze the actual influence of IT on quality of controlling outputs and results because the user personal experience with IT solution has the ability to influence the overall controlling effectiveness. Perceived level of IT reliability is offering some sort of insight on that giving the opportunity to analyze aspects of IT use, such as: usability or system and service reliability.

Hence, the following research hypotheses can be formulated:

- $\quad$ H3: In organizations with lower IT reliability, the influence of controlling time of use on the quality of controlling outputs is weaker than in organizations with higher IT reliability. IT reliability is a moderator for the 
relation between controlling time of use and the quality of the controlling outputs.

- H4: In organizations with lower IT reliability, the influence of controlling time of use on the results obtained due to controlling implementation is weaker than in organizations with higher IT reliability. IT reliability is a moderator for the relation between controlling time of use and results obtained due to controlling implementation.

- H5: In organizations with lower IT reliability, the influence of the quality of controlling outputs on the results obtained due to controlling implementation is weaker than in organizations with higher IT reliability. IT reliability is a moderator for the relation between quality of controlling outputs and results obtained due to controlling implementation.

All developed hypotheses, showing the relation between IT reliability, controlling time of use, quality of controlling outputs and results obtained due to controlling implementation, are presented on Figure 2.

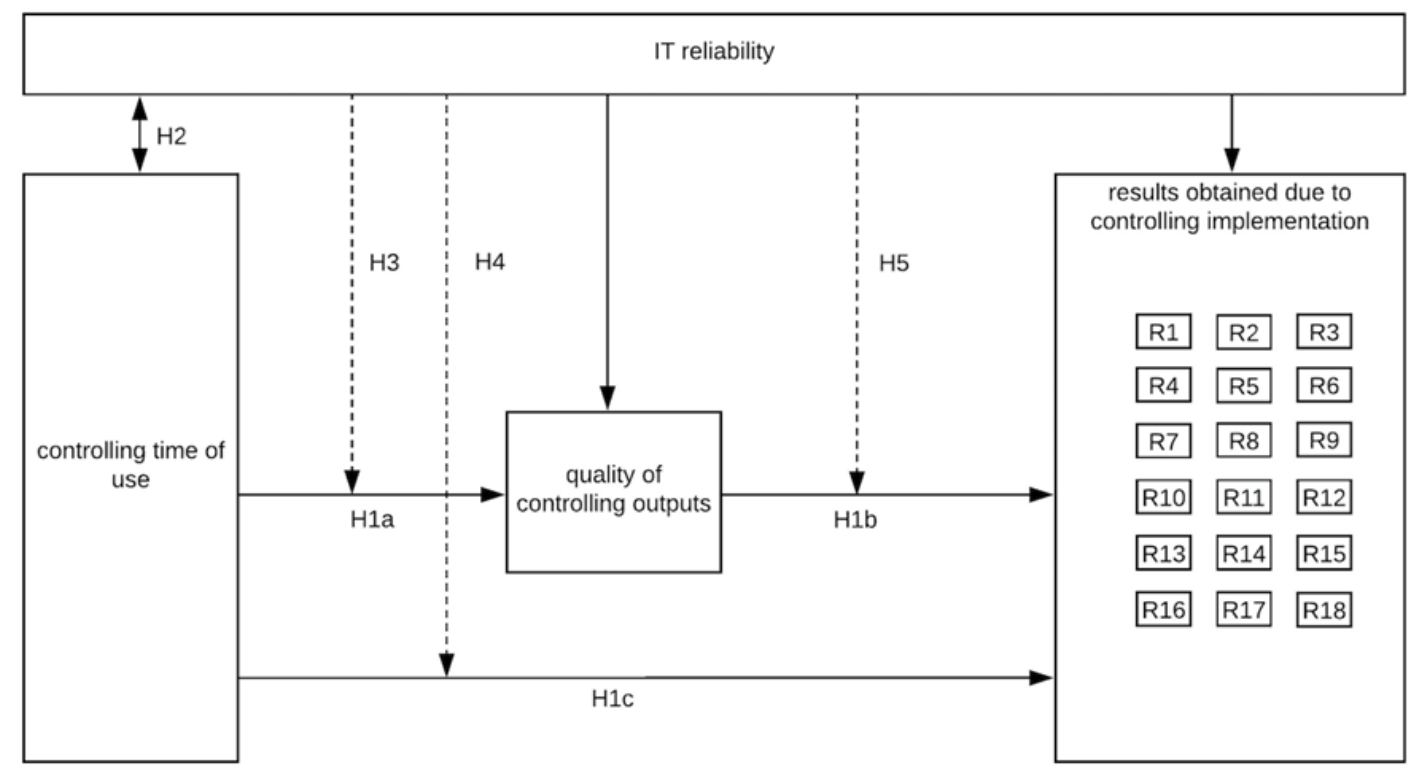

Figure 2. Developed hypotheses

\section{RESEARCH METHODOLOGY AND RESULTS}

The survey was conducted in order to verify the proposed hypotheses and identify the level of IT reliability, controlling time of use, quality of controlling outputs 
and results obtained due to controlling implementation for every considered organization. The main survey was preceded by the pilot survey conducted in early 2018 among the group of 50 organizations in order to explain the issues concerning ambiguity of several questions. According to obtained results, the ambiguous questions were rewritten in order to obtain more informed response from the organizations participating in main survey. The main research was conducted as a part of a research project "The IT reliability influence on the quality of management methods and techniques”, no. 2017/01/X/HS4/01967 financed from the funds of the National Science Center in Poland. The main survey was conducted in March 2018, among organizations located in Poland, which was the only condition limiting the sample (regardless of size, industry or type of business etc.), using online survey service: SurveyMonkey. Only one survey was carried out anonymously in one organization, and it was completed by employees who have a broad view of the entire organization. Efforts had been made to make sure that the questionnaire was filled by organizations of all sizes and all types. Sample characteristic presented in Table 1 seems to confirm this. 557 valid responses were collected, which is a very large sample for this kind of study. Out of that sample, 532 organizations have declared the implementation of controlling solutions, and process of hypotheses verification was based on that part of the sample.

\begin{tabular}{lcccc}
\hline Organization size & $\begin{array}{c}\text { Manufacturing } \\
\text { organizations }\end{array}$ & $\begin{array}{c}\text { Service } \\
\text { organizations }\end{array}$ & $\begin{array}{c}\text { Trade } \\
\text { organizations }\end{array}$ & Total \\
\hline Micro (below 10 people) & 66 & 31 & 10 & 106 \\
Small (11-50 people) & 48 & 72 & 20 & 140 \\
Medium (51-250 people) & 42 & 77 & 15 & 134 \\
Large (above 250 people) & 71 & 92 & 14 & 177 \\
Total & 227 & 272 & 59 & 557 \\
\hline
\end{tabular}

Table 1. Research sample characteristics (Bieńkowska et al., 2018)

\subsection{Variables measurement}

In order to examine the relation between IT reliability, controlling time of use and results of controlling, key variables were defined: IT reliability (consisting of IT system reliability (including IT usage reliability), IT information reliability, IT service reliability), controlling time of use, quality of controlling outputs and results obtained due to controlling implementation. Except from the variable 
controlling time of use, respondents evaluated all others variables basing on the list of factors and using the Likert scale (from very poor to very good with the middle point: fair).

Using a Likert scale to measure IT reliability seems to be an appropriate choice. First of all, reliability of IT in organization is a subjective notion. Employees own perspective and opinion concerning aspects of IT reliability is the best source of knowledge, since their perception matters the most that is because IT influences the organization mainly through its potential to influence every-day work of the employees. Quantitative methods are commonly used to assess the software and hardware features linked to the reliability. However, they do not give the information concerning the actual perception of this notion within the organization (Tworek, 2018a).

With reference to time of use of controlling in organization, respondents were asked to indicate how long controlling operates in organization using specified intervals (not used, recently implemented, used more than a year, used more than 5 years, used more than 10 years).

The results that are expected after the implementation of controlling can be considered from two perspectives:

- from the perspective of controlling clients, i.e. managerial staff, managers of responsibility centers, considering direct outputs of controlling;

- from the perspective of the organization itself, considering indirect results obtained by the organization due to controlling implementation (Bieńkowska et al., 2018).

Hence, the two key variables concerning the results of controlling were defined: quality of controlling outputs and results obtained due to controlling implementation.

Respondents were asked to evaluate the quality of controlling outputs based on the list of 9 statements using the typical Likert scale. In particular, reference was made to elements directly affected by controlling - budgeting and information provided to managers for the purposes of decision making (including reports and analyzes). In a very similar way, using the same Likert scale, respondents evaluated results obtained due to controlling implementation. The identified 
results (the list consists of 18 items - see tab. 5) are related to the functioning of the organization as a whole.

\subsection{Descriptive statistics and reliability analysis of scales}

As a first step in a research process, the reliability of scales was verified and is presented in Table 2. For results obtained due to controlling implementation, the analysis of the reliability was not done (Cronbach's $\alpha$ was not counted) as they do not create a common variable. It is worth noting that Cronbach's $\alpha$ was high for every variable, which indicates a high internal reliability of the scales and measurements. Descriptive statistics were calculated for all measured variables and are presented in Table 3.

\begin{tabular}{cccc}
\hline No. & \multicolumn{1}{c}{ Variable } & No. of scales & Alfa-Cronbacha \\
\hline 1 & IT reliability & 28 & 0,947 \\
2 & system reliability & 15 & 0,945 \\
3 & usage reliability & 6 & 0,919 \\
4 & information reliability & 7 & 0,929 \\
5 & service reliability & 6 & 0,919 \\
6 & Controlling time of use & 1 & - \\
7 & Quality of controlling outputs & 9 & 0,916 \\
8 & Results obtained due to controlling implementation & 18 & was not counted \\
\hline & Table 2. Defined variables along with the results of the reliability analysis of scales
\end{tabular}

\begin{tabular}{lccccc}
\hline & Average & Median & Min & Max & $\begin{array}{c}\text { Std. } \\
\text { deviation }\end{array}$ \\
\hline $\begin{array}{l}\text { IT reliability } \\
\text { system reliability }\end{array}$ & 3,73 & 4,00 & 1,44 & 5,00 & 1,00 \\
$\quad$ information reliability & 3,74 & 4,00 & 1,39 & 5,00 & 0,98 \\
$\quad \begin{array}{l}\text { service reliability } \\
\text { Quality of controlling } \\
\text { outputs }\end{array}$ & 3,79 & 4,00 & 1,43 & 5,00 & 1,02 \\
$\begin{array}{l}\text { Controlling time of } \\
\text { use }\end{array}$ & 2,60 & 2,56 & 1,00 & 5,00 & 0,91 \\
$\begin{array}{l}\text { Results obtained due } \\
\text { to controlling } \\
\text { implementation } \\
\text { (based on average) * }\end{array}$ & 3,28 & 3,00 & 1,00 & 5,00 & 1,19 \\
\hline
\end{tabular}

Table 3. Descriptive statistics of measured variables 


\subsection{Controlling time of use, IT reliability, quality of controlling outputs}

In order to verify hypotheses $\mathrm{H} 1 \mathrm{a}$ and $\mathrm{H} 2$, the correlation between controlling time of use and the IT reliability as well as quality of controlling outputs was calculated as the first part of the study (Table 4). The results show that IT reliability is statistically significantly correlated with the controlling time of use in an organization, although correlation does not allow us to conclude on the direction of this dependence. Table 4 includes also the correlation analysis between the IT reliability and quality of controlling outputs. This relation has already been examined in (Bieńkowska et al., 2018) and only the final results of these analyzes are given here. The results clearly show that there is a statistically significant correlation between IT reliability (in a fact in every aspect of IT reliability, although the biggest in case of usage and information reliability) and quality of controlling outputs. Hence, both hypotheses have been positively verified.

\begin{tabular}{|c|c|c|}
\hline & IT reliability & $\begin{array}{l}\text { Quality of controlling } \\
\text { outputs }\end{array}$ \\
\hline Controlling time of use & $r(532)=0,485^{* *}, p=0,001$ & $r(532)=0,089^{*}, p<0,05$ \\
\hline $\begin{array}{l}{ }^{*} \text { ) correlation of } \mathrm{r} \text {-Pearson is } \mathrm{s} \\
{ }^{* *} \text { ) correlation of } \mathrm{r} \text {-Pearson is }\end{array}$ & $\begin{array}{l}5 \text { (two-sided) } \\
01 \text { (two-sided) }\end{array}$ & \\
\hline
\end{tabular}

Table 4. Relation between the IT reliability, quality of controlling outputs and controlling time

\subsection{Results obtained due to controlling implementation}

The relation between results obtained by the organization due to the controlling implementation, quality of controlling outputs and controlling time of use was analyzed with the use of r-Pearson correlation in order to verify the hypotheses $\mathrm{H} 1 \mathrm{~b}$ and H1c. The results are presented in table 5.

The results show that controlling time of use is statistically significantly correlated with all results obtained due to the controlling implementation, which positively verifies the hypothesis H2. However, the results of the correlation analysis between quality of controlling outputs and results obtained due to controlling implementation show that quality of controlling outputs is statistically significantly correlated with only a part of them (11 from 18) and in a lot of cases this correlation is mild. Moreover, it must be underlined that correlation between quality of controlling outputs and adaptation of the organization to changes taking 
place in the environment (R1) is strong and negative, which is unexpected. These relations are a bit surprising and were already discussed in a paper published by Bieńkowska et al. (2018). Hence, it allows for the partial verification of the H1b hypothesis.

\begin{tabular}{|c|c|c|c|c|}
\hline & $\begin{array}{l}\text { Results obtained due to controlling } \\
\text { implementation }\end{array}$ & IT reliability & $\begin{array}{l}\text { Quality of } \\
\text { controlling } \\
\text { outputs }\end{array}$ & $\begin{array}{l}\text { Controlling } \\
\text { time of use }\end{array}$ \\
\hline R1 & $\begin{array}{l}\text { Adaptation of the organization to } \\
\text { changes taking place in the } \\
\text { environment }\end{array}$ & $\begin{array}{c}r(532)=0,348^{* *} \\
p<0,001\end{array}$ & $\begin{array}{c}r(531)=-0,153^{* *} \\
p<0,001\end{array}$ & $\begin{array}{c}r(532)=0,348^{* *}, \\
p<0,01\end{array}$ \\
\hline $\mathrm{R} 2$ & $\begin{array}{l}\text { Improvement of the organization's } \\
\text { competitiveness }\end{array}$ & $\begin{array}{l}r(511)=0,235^{* *} \\
p<0,001\end{array}$ & $\begin{array}{l}r(462)=0,045 \\
p=0,314\end{array}$ & $\begin{array}{c}r(470)=0,347^{* *} \\
p<0,01\end{array}$ \\
\hline R3 & $\begin{array}{l}\text { Increase of the chances for the long- } \\
\text { term existence of the organization }\end{array}$ & $\begin{array}{l}r(498)=0,292^{* *} \\
p<0,001\end{array}$ & $\begin{array}{c}r(464)=-0,033 \\
p=0,467\end{array}$ & $\begin{array}{c}r(482)=0,357^{* *}, \\
p<0,01\end{array}$ \\
\hline R4 & $\begin{array}{l}\text { Overall increase in the efficiency of } \\
\text { the organization's management }\end{array}$ & $\begin{array}{c}r(491)=0,239^{* *} \\
p<0,001\end{array}$ & $\begin{array}{c}r(471)=0,021 \\
p=0,652\end{array}$ & $\begin{array}{c}r(478)=0,341^{* *}, \\
p<0,001\end{array}$ \\
\hline R5 & $\begin{array}{l}\text { More effective achievement of the } \\
\text { organization's goals }\end{array}$ & $\begin{array}{c}r(485)=0,172^{* *} \\
p<0,001\end{array}$ & $\begin{array}{c}r(511)=0,112^{*} \\
p=0,014\end{array}$ & $\begin{array}{c}r(510)=0,378^{* *} \\
p<0,01\end{array}$ \\
\hline R6 & $\begin{array}{l}\text { Shortening of the decision-making } \\
\text { time }\end{array}$ & $\begin{array}{c}r(485)=0,079 \\
p=0,083\end{array}$ & $\begin{array}{c}r(497)=0,185^{* *}, \\
p<0,001\end{array}$ & $\begin{array}{c}r(461)=0,269^{* *} \\
p<0,01\end{array}$ \\
\hline R7 & $\begin{array}{l}\text { Better flow of information inside the } \\
\text { organization }\end{array}$ & $\begin{array}{c}r(476)=0,232^{* *} \\
p<0,001\end{array}$ & $\begin{array}{c}r(456)=0,069 \\
p=0,131\end{array}$ & $\begin{array}{c}r(459)=0,159^{* *} \\
p<0,01\end{array}$ \\
\hline R8 & $\begin{array}{l}\text { Increase of satisfaction and increase } \\
\text { of employee morale }\end{array}$ & $\begin{array}{c}r(476)=0,220^{* *} \\
p<0,001\end{array}$ & $\begin{array}{c}r(467)=0,009 \\
p=0,852\end{array}$ & $\begin{array}{c}r(487)=0,188^{* *} \\
p<0,01\end{array}$ \\
\hline R9 & $\begin{array}{l}\text { Increase in employee involvement in } \\
\text { achieving results }\end{array}$ & $\begin{array}{c}r(476)=0,232^{* *} \\
p<0,001\end{array}$ & $\begin{array}{c}r(485)=0,160^{* *} \\
p<0,001\end{array}$ & $\begin{array}{c}r(481)=0,147^{* *} \\
p<0,01\end{array}$ \\
\hline R10 & $\begin{array}{l}\text { Improvement of the competence of } \\
\text { employees }\end{array}$ & $\begin{array}{c}r(474)=0,213^{* *} \\
p<0,001\end{array}$ & $\begin{array}{c}r(484)=0,132^{* *} \\
p=0,004\end{array}$ & $\begin{array}{c}r(489)=0,144^{* *}, \\
p<0,01\end{array}$ \\
\hline R11 & $\begin{array}{l}\text { General improvement of the } \\
\text { organization's financial results }\end{array}$ & $\begin{array}{c}r(469)=0,260^{* *} \\
p<0,001\end{array}$ & $\begin{array}{c}r(471)=0,173^{* *} \\
p<0,001\end{array}$ & $\begin{array}{c}r(465)=0,272^{* *} \\
p<0,01\end{array}$ \\
\hline R12 & $\begin{array}{l}\text { More effective and more rational } \\
\text { management of the organization's } \\
\text { resources }\end{array}$ & $\begin{array}{c}r(467)=0,232^{* *} \\
p<0,001\end{array}$ & $\begin{array}{c}r(474)=0,145^{* *} \\
p=0,002\end{array}$ & $\begin{array}{c}r(472)=0,204^{* *} \\
p<0,01\end{array}$ \\
\hline R13 & Increase in the quality of products & $\begin{array}{c}r(469)=0,261^{* *} \\
p<0,001\end{array}$ & $\begin{array}{c}r(472)=0,083 \\
p=0,073\end{array}$ & $\begin{array}{c}r(479)=0,243^{* *} \\
p<0,01\end{array}$ \\
\hline R14 & $\begin{array}{l}\text { Improvement of the timeliness of } \\
\text { production orders }\end{array}$ & $\begin{array}{c}r(466)=0,277^{* *} \\
p<0,001\end{array}$ & $\begin{array}{c}r(465)=0,106^{*} \\
p=0,022\end{array}$ & $\begin{array}{c}r(467)=0,217^{* *} \\
p<0,01\end{array}$ \\
\hline R15 & $\begin{array}{l}\text { Increase in the number of changes in } \\
\text { products / services }\end{array}$ & $\begin{array}{c}r(467)=0,173^{* *} \\
p<0,001\end{array}$ & $\begin{array}{c}r(469)=0,094^{*} \\
p=0,042\end{array}$ & $\begin{array}{c}r(462)=0,167^{* *} \\
p<0,01\end{array}$ \\
\hline R16 & $\begin{array}{l}\text { Increase in the number of changes in } \\
\text { business processes }\end{array}$ & $\begin{array}{c}r(465)=0,258^{* *} \\
p<0,001\end{array}$ & $\begin{array}{c}r(470)=0,150^{* *} \\
p=0,001\end{array}$ & $\begin{array}{c}r(465)=0,125^{* *} \\
p<0,01\end{array}$ \\
\hline R17 & $\begin{array}{l}\text { Increase in the number of } \\
\text { organizational changes }\end{array}$ & $\begin{array}{c}r(472)=0,215^{* *} \\
p<0,001\end{array}$ & $\begin{array}{c}r(458)=0,078 \\
p=0,091\end{array}$ & $\begin{array}{c}r(466)=0,151^{* *} \\
p<0,01\end{array}$ \\
\hline R18 & $\begin{array}{l}\text { Increase in the number of marketing } \\
\text { changes }\end{array}$ & $\begin{array}{c}r(474)=0,174^{* *} \\
p<0,001\end{array}$ & $\begin{array}{c}r(471)=0,092^{*} \\
p=0,045\end{array}$ & $\begin{array}{c}r(469)=0,179^{* *}, \\
p<0,01\end{array}$ \\
\hline
\end{tabular}

*) correlation of $r$-Pearson is significant at the level of 0.05 (two-sided)

${ }^{* *}$ ) correlation of $r$-Pearson is significant at the level of 0.01 (two-sided)

Table 5. Correlation analysis 


\subsection{IT reliability as a moderator for the relations between controlling time of use and quality of controlling outputs}

The relation between controlling time of use and quality of controlling outputs was analyzed in the context of IT reliability (hypothesis H4). Regression analysis with moderator was used to determine whether IT reliability is significantly moderating the relation between controlling time of use and quality of controlling outputs.

As a first step, new variable - moderator - was introduced. The moderator variable is built as a product of standardized variables: controlling time of use and IT reliability. As a second step, 3 regression models for quality of controlling outputs as a dependent variable were built in IBM SPSS Statistics. The first model was built as a base model for comparison, only controlling time of use and IT reliability were added as predictors (coefficients are presented in Table 6). The model was statistically significant $(\mathrm{F}(2,567)=24,863, \mathrm{p}<0,001)$ and corrected $\mathrm{R} 2$ was equal 0,081 . However, controlling time of use was excluded as a predictor ( $\mathrm{B}$ $=0,002, \mathrm{p}=0,947)$, which is a basis for conclusion that controlling time of use itself does not statistically significantly explain the variance of quality of controlling outputs.

The second model was built using controlling time of use and IT reliability together with the moderator as predictors to verify whether the moderating influence is occurring in the sample. The model was also statistically significant $(0,168 \mathrm{~F}(3,566)=39,377, \mathrm{p}<0,001)$ and indeed, the moderating effect occurred because R2 had risen tremendously (by more than 100\%) to the value of 0,168 . Moreover, the significance level in case of controlling time of use dropped from 0,947 to 0,612 in the second model - it was still insignificant as a predictor but it confirmed that moderating effect occurs (coefficients are presented in Table 7). All that suggested that IT reliability is statistically significantly moderating the relation between controlling time of use and quality of controlling outputs.

To confirm that the third regression model was built using only controlling time of use and the moderator as predictors, in this model, which was also statistically significant $(\mathrm{F}(2,567)=36,353, \mathrm{p}<0,001)$ not only the moderator but also controlling time of use was finally verified as a statistically significant predictor of quality of controlling outputs (coefficient are presented in Table 8). The fact that it occurred in the third model, where it was analyzed together with the 
proposed moderator, is the final confirmation that IT reliability indeed has a statistically significant moderating role for the relation between controlling time of use and quality of controlling outputs. This conclusion allows for the positive verification of $\mathrm{H} 4$ hypothesis.

\begin{tabular}{lllll}
\hline & Coeff. & $\begin{array}{l}\text { Standard } \\
\text { error }\end{array}$ & $\boldsymbol{t}$ Stat & P Value \\
\hline Constant & 3,366 & 0,186 & 18,117 & $<0,001$ \\
\hline Controlling time of use & 0,002 & 0,032 & 0,067 & 0,947 \\
\hline IT reliability & 0,286 & 0,043 & 6,609 & $<0,001$ \\
\hline
\end{tabular}

Table 6. Coefficients for $1^{\text {st }}$ regression model

\begin{tabular}{lllll}
\hline & Coeff. & $\begin{array}{l}\text { Standard } \\
\text { error }\end{array}$ & t Stat & P Value \\
\hline Constant & 3,219 & 0,177 & 18,149 & 0,001 \\
\hline Controlling time of use & 0,016 & 0,031 & 0,507 & 0,612 \\
\hline IT reliability & 0,262 & 0,041 & 6,346 & $<0,001$ \\
\hline Moderator & 0,235 & 0,030 & 7,928 & $<0,001$ \\
\hline
\end{tabular}

Table 7. Coefficients for $2^{\text {nd }}$ regression model

\begin{tabular}{lllll}
\hline & Coeff. & $\begin{array}{l}\text { Standard } \\
\text { error }\end{array}$ & $\boldsymbol{t}$ Stat & P Value \\
\hline Constant & 2,294 & 0,104 & 21,8955 & $<0,001$ \\
\hline Controlling time of use & 0,086 & 0,030 & 8,150 & $<0,001$ \\
\hline Moderator & 0,249 & 0,031 & 2,903 & 0,004 \\
\hline
\end{tabular}

Table 8. Coefficients for $3^{\text {rd }}$ regression model

\subsection{IT reliability as a moderator for the relations between quality of controlling outputs and results obtained due to controlling implementation}

The relation between quality of controlling outputs and results obtained due to controlling implementation was also analyzed in the context of IT reliability in order to verify hypothesis H5. Regression analysis with moderator was used to determine whether IT reliability is significantly moderating that relation. New variable - another moderator - was introduced. The moderator variable in this case is built as a product of standardized variables: quality of controlling outputs and IT reliability. Next, 3 regression models (as in the case described in details above) for each result obtained due to controlling implementation as a dependent variable were built in IBM SPSS Statistics to verify whether IT reliability was a statistically significant moderator. IT reliability proved to be a moderator of the relation between quality of controlling outputs and R1, R3, R7, R10, R11, R12 
and R14 (regression models statistics are presented in Table 9). Hence, based on that results it may be concluded that hypothesis H6 was partially, positively verified.

\begin{tabular}{|c|c|c|c|c|c|c|}
\hline & Predictors. & Delta $R^{2}$ & $\begin{array}{l}\text { Moderator } \\
\text { coeff. }\end{array}$ & $\begin{array}{l}\text { Standard } \\
\text { error }\end{array}$ & t Stat & $\begin{array}{l}P \\
\text { Value }\end{array}$ \\
\hline $\mathrm{R} 1$ & $\begin{array}{l}\text { IT reliability, } \\
\text { quality of controlling } \\
\text { outputs, moderator }\end{array}$ & $\begin{array}{l}0,204- \\
0,191\end{array}$ & 0,095 & 0,031 & 3,050 & 0,002 \\
\hline R3 & $\begin{array}{l}\text { IT reliability, } \\
\text { quality of controlling } \\
\text { outputs, moderator }\end{array}$ & $\begin{array}{l}0,107- \\
0,091\end{array}$ & 0,100 & 0,034 & 2,927 & 0,004 \\
\hline R7 & $\begin{array}{l}\text { IT reliability, } \\
\text { quality of controlling } \\
\text { outputs, moderator }\end{array}$ & $\begin{array}{l}0,084- \\
0,056\end{array}$ & 0,123 & 0,032 & 3,813 & 0,001 \\
\hline R10 & $\begin{array}{l}\text { IT reliability, } \\
\text { quality of controlling } \\
\text { outputs, moderator }\end{array}$ & $\begin{array}{l}0,089- \\
0,054\end{array}$ & 0,128 & 0,030 & 4,218 & 0,001 \\
\hline R11 & $\begin{array}{l}\text { IT reliability, } \\
\text { quality of controlling } \\
\text { outputs, moderator }\end{array}$ & $\begin{array}{l}0,129- \\
0,084\end{array}$ & 0,130 & 0,027 & 4,886 & 0,001 \\
\hline R12 & $\begin{array}{l}\text { IT reliability, } \\
\text { quality of controlling } \\
\text { outputs, moderator }\end{array}$ & $\begin{array}{l}0,106- \\
0,057\end{array}$ & 0,165 & 0,033 & 5,017 & 0,001 \\
\hline R14 & $\begin{array}{l}\text { IT reliability, } \\
\text { quality of controlling } \\
\text { outputs, moderator }\end{array}$ & $\begin{array}{l}0,092- \\
0,075\end{array}$ & 0,089 & 0,031 & 2,911 & 0,004 \\
\hline
\end{tabular}

Table 9. Regression model statistics

\subsection{IT reliability as a moderator for the relations between controlling time of use and results obtained due to controlling implementation}

In order to verify hypothesis $\mathrm{H} 4$, the relation between controlling time of use and results obtained due to controlling implementation was also analyzed in the context of IT reliability. Regression analysis with moderator was used to determine whether IT reliability is significantly moderating that relation (as in the cases described in details above). Unfortunately, in this case IT reliability wasn't proved to be a moderator of the relation between controlling time of use and results obtained due to controlling implementation, what is the basis for a negative verification of the $\mathrm{H} 5$ hypothesis. 


\subsection{Synthetic results of the research}

The obtained synthetic results of the research are presented on Fig. 3.

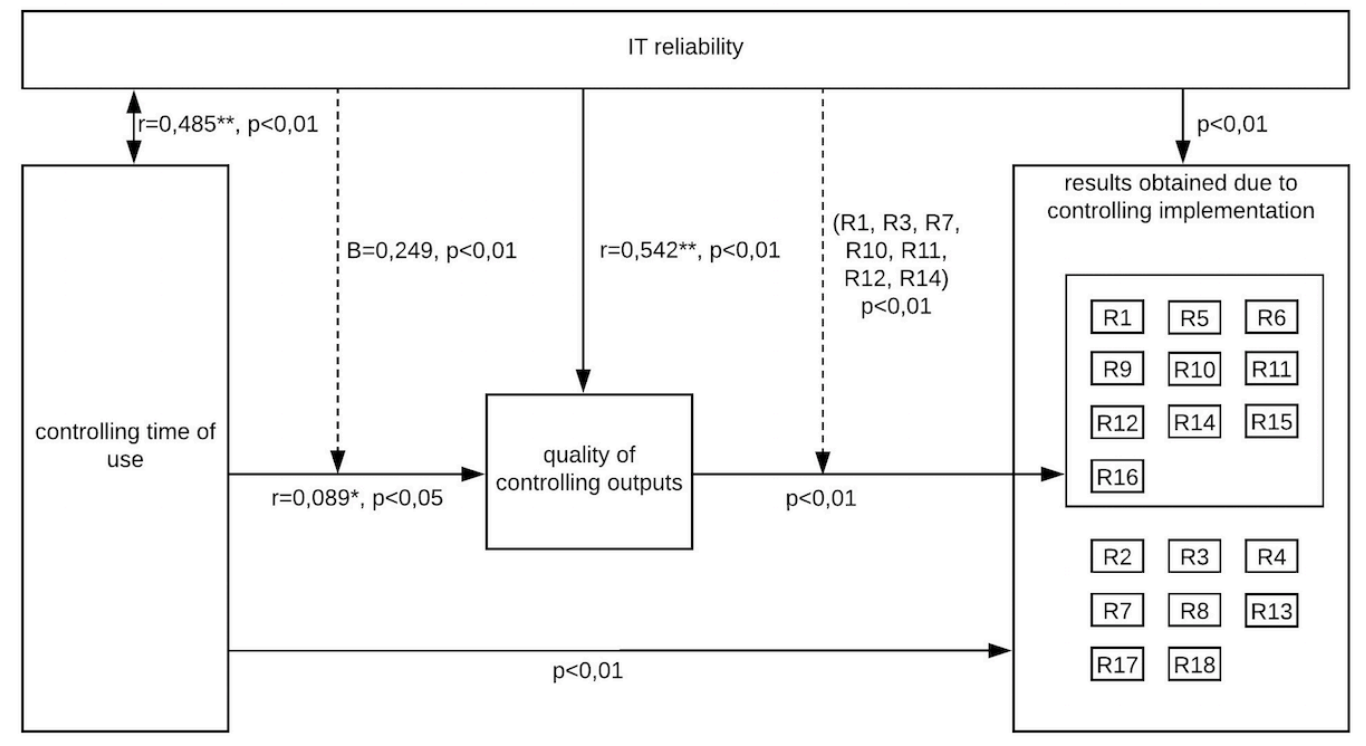

Figure 3. Synthetic results of the research

\section{DISCUSION}

Controlling is a management support method that can be characterized by extremely dynamic and changing nature. Observation of the development of the controlling concept over the last century leads to the conclusion that there is no single standard for controlling solutions, and even in similar conditions, the shape of controlling solutions in individual organizations may differ, and moreover, evolve differently over time. The scope and complexity of the adopted controlling solutions determine the quality of controlling outputs that can be obtained and the potential range of results obtained by the organization due to the implementation of controlling. However, this statement should not be accepted as proof that with the increase in the complexity of controlling solutions, the quality of controlling outputs is growing. It should be rather assumed that it is dependent on the adaptation of controlling solutions to the existing internal and external conditions. Only then the expected results may appear. The literature also emphasizes that "controlling must constantly keep up with changes in external and internal conditions (...) look for new solutions" (Grudziński, 2008). However, it is difficult 
to agree with the statement of Goliszewski (2015) that the implementation of controlling becomes permanent process. The authors assume that the implementation process of controlling is limited in time, and after it is finished, the controlling system matures and improves according to changes in conditions, and only this is a permanent process. Controlling is a subject of this maturation more than it is assumed. First of all, it matures and develops under the influence of its functioning in the organization. Assuming real and conscious use of the implemented solutions, the gradually acquired proficiency in operating controlling instruments and understanding its essence favor the search for more and better ways to implement the functions and tasks of controlling. In turn, it enables delivery of products in accordance with the expectations of controlling. The conducted research confirmed this thesis. As predicted, in the light of research findings and theoretical considerations outlined above, controlling time of use is positively related with the quality of controlling outputs and strongly positively related with all results obtained due to controlling implementation.

However, the main focus of this paper is to define the role of IT in the process of striving for the excellence of controlling. It was assumed that controlling is one of methods, which is highly sensitive to the IT influence (Bogt et al., 2016; Goto et al., 2014). First of all, it was stated that there is a strong positive relation between IT reliability and the quality of controlling outputs and some of the results that the organization can obtain due to IT implementation (Bieńkowska et al., 2018), which means that the more reliable the IT, the better the controlling itself works and the better the organization results obtained due to its implementation. Moreover, it turned out (and was confirmed by the results of the research presented in this paper) that there is a strong positive relation between the controlling time of use in the organization (which was initially assumed as a benchmark for striving for controlling excellence, assuming constant changes in the organization) and IT reliability. At the same time, determining the direction of this influence is not so clear. Because in the process of implementing controlling, IT systems are the initial precondition for the correct implementation of this method (i.e. the lack of IT prevents the implementation of controlling), so IT affects the time of controlling use. However, afterwards, when the implementation process is over, the relation may also be reversed. Controlling, having specific requirements, enforces changes in IT and thus affects IT reliability. Over time, under the influence of the tasks of controlling and changing conditions of the 
organization functioning, there is a change of controlling (no only substantive and also instrumental solutions), including those related to IT. Along with the extension of the controlling time of use, the reliability of IT controlling solutions in the organization grows broadly. Users "learn" IT solutions, acquire proficiency and skills in handling them in the implementation of controlling tasks, and after some time are able to even configure them appropriately in terms of the ability to collect and process the necessary information, which affects their subjectively perceived, better assessment of IT reliability. It is important to underline here that this subjective perception of IT reliability gives an important feedback - that IT becomes more aligned with the requirements of controlling in organization with the extension of controlling time of use. As assumed, the relation is two-sided. The increase of IT reliability is conducive to obtaining better quality of controlling outputs, which in turn is a strong argument for further use of this method (i.e. extending the time of its use in the organization). Therefore, both statements are true: 1) the higher IT reliability, the longer controlling time of use, and 2) the longer controlling time of use, the higher the IT reliability.

However, the most interesting observations are related to the impact of IT reliability on the relation between the controlling time of use, the quality of its outputs and the results obtained due to its implementation. That reveals the indirect impact of IT reliability on the improvement of controlling in time, and consequently on its maturity and striving for excellence. The obtained results confirmed that IT reliability is a moderator for the relation between controlling time of use and the quality of the controlling outputs. This means that IT strengthens this influence in the organization. In organizations where the longer time of use of controlling is accompanied by high reliability of IT, the quality of controlling outputs is assessed as statistically significantly higher than in organizations where IT reliability is lower. Therefore, it can be concluded that IT has an important role in the process of controlling maturation, as it strengthens the impact of controlling time of use on the quality of its outputs. Based on that, it can be stated that in organizations with reliable IT, the quality of controlling outputs grows faster than in other ones. Regarding the results obtained due to the implementation of controlling, IT reliability also proved to be a moderator of the relation between the quality of controlling outputs and results obtained due to controlling implementation. However, IT reliability proved to be a statistically significant moderator not for all, but for a few of identified results. Organizations, 
in which the controlling time of use is longer and accompanied by high reliability of IT, are better adapting to changes taking place in the environment. They also have a better chance for the long-term existence, observe a better flow of information, improvement of financial results, more effective and more rational management of the organization resources and improvement of the timeliness of production orders. In such organizations, the increase of employees' competences is also observed. Although the results show that IT reliability is statistically significantly correlated with almost all results obtained due to controlling implementation (except one) and the quality of controlling outputs, it is not a statistically significant moderator of the relation between controlling time of use and those results. Controlling influences the work of managers directly, which improves the quality of management (Bieńkowska, 2015), and only then the managers improve the performance of the organization as a whole. In this way, the influence of IT reliability on the processes of improvement of the controlling itself is proven through the time of its use in the organization, the quality of its outputs, as well as the results obtained due to its implementation. As a result, the significant influence of IT reliability on controlling excellence can be assumed.

\section{CONCLUSIONS}

The aim of the article was to identify what is the IT reliability influence on controlling excellence. The analysis concerned relations between the time of use (maturity and excellence) of controlling, the quality of its outputs, the results obtained due to its implementation in organization and IT reliability as a moderator of changes in controlling in the organization. To achieve this aim, questionnaire surveys were carried out among 557 companies, and 532 of them declared the implementation of controlling. Research has shown that IT reliability not only affects the quality of controlling outputs and the results obtained due to its implementation in the organization, but also that there is a strong (two-way) relations between IT reliability and the time of controlling use in organization. Moreover, IT reliability is a moderator of the relation (strengthens it) between the controlling time of use and the quality of its outputs, as well as between the quality of its outputs and the results obtained due to its implementation. All the above proves the important role of reliable IT in the pursuit of controlling excellence. 
It is important to underline that the research has some limitations. The abovementioned hypotheses were verified based on only one research sample. The sample was large. However, it was not large and diverse enough to be considered as a representative sample of all organizations from Poland. Moreover, it allowed for the verification of the hypotheses in only one business context. Hence, the further verification of conclusions presented in this paper is needed. Moreover, Likert scale used for the questionnaire (qualitative analysis) makes the results highly dependable on the perception of employees filling in the questionnaire, which makes it susceptible to personal bias. However, the large size of the sample should limit this possible (but not sure) negative effect.

The performed research causes some new questions to arise. Is it really true that controlling time of use is a determinant of its improvement processes? The results of the research prove that this happens due to the permanent changes, to which controlling is a subject over time. However, it would be possible to refine the research by analyzing types of changes made in controlling over the course of its functioning in the organization. It may turn out that some types of changes (i.e. in the scope of tasks performed by controllers, implementation of adjusted solutions in the scope of the information and reporting system) will be subject to greater moderation by reliable IT than others. The obtained results are a solid first step in the analysis of IT role in striving for controlling maturity and excellence and establish directions for further research.

\section{Acknowledgements}

The paper was created as a result of the research project no. 2017/01/X/HS4/01967 financed from the funds of the National Science Center. 


\section{REFERENCES}

BIEŃKOWSKA A. (2015): „Analiza rozwiązań i wzorce controllingu w organizacji”, Oficyna Wydawnicza Politechniki Wrocławskiej, Wrocław.

BIEŃKOWSKA, A., ZGRZYWA-ZIEMAK, A. (2011): „Współczesne metody zarządzania w przedsiębiorstwach funkcjonujących w Polsce - identyfikacja stanu istniejącego”, [in:] Hopej, M., Kral, Z. (eds.) “Współczesne metody zarządzania w teorii i praktyce”, Oficyna Wydawnicza Politechniki Wrocławskiej, Wrocław.

BIEŃKOWSKA A., TWOREK K., ZABŁOCKA-KLUCZKA A. (2018): “IT Reliability and the Results of Controlling”, [in:] Wilimowska Z., Borzemski L., Świątek J. (eds) Information Systems Architecture and Technology: Proceedings of 39th International Conference on Information Systems Architecture and Technology - ISAT 2018. ISAT 2018. Advances in Intelligent Systems and Computing, vol. 854, Springer, Cham, https://doi.org/10.1007/978-3-319-999937_20.

BOGT, H. T., van HELDEN, J., \& van der KOLK, B. (2016): “New development: Public sector controllership-reinventing the financial specialist as a countervailing power”, Public Money \& Management, vol. 36, n. 5: 379-384, https://doi.org/10.1080/09540962.2016.1194086.

CHACHUŁA D. (2009): „Fazy rozwoju controllingu - wyniki badań”, Controlling i Rachunkowość Zarządcza, n. 4: 29-32.

CROWSTON K. (2000): "Processes as theory in information systems research", Arlborg, Niemcy, International Working Conference on the Social and Organizational Perspective on Research and Practice in Information Technology, pp. 149-164, https://doi.org/10.1007/978-0-387-35505-4_10.

DAVIS, F. D. (1985): “A technology acceptance model for empirically testing new end-user information systems: Theory and results” (Doctoral dissertation, MIT).

DELONE, W. H., \& MCLEAN, E. R. (2003): “The DeLone and McLean model of information systems success: a ten-year update. Journal of management information systems”, vol. 19, n.4: 9-30, https://doi.org/10.1080/07421 222.2003.11045748. 
GOLISZEWSKI J. (2015): “Controlling. Koncepcja, zastosowanie, wdrożenie”, Oficyna a Wolters Kluwer Business, Warszawa.

GOTO, E. P., PARISI, C., \& SLOMSKI, V. G. (2014): “The Influence of Contigency Factors in the Area of Divisional Controllership in Foreign Subsidiaries of a Multinational Organization”, Business Management Review, vol. 4, n. 3: 367-382.

GRUDZIŃSKI J. (2008): "Meandry wdrażania idei controlling w Południowym Koncernie Energetycznym S.A.”, Controlling i Rachunkowość Zarządcza, n. 3.

HOSSEINI, S., BARKER, K., \& RAMIRES-MARQUEZ, J. E. (2016): A review of definitions and measures of system resilience. Reliability Engineering \& System Safety, vol. 145: 47-61, https://doi.org/10.1016/j.ress.2015.08.006.

IRANI, Z. (2002): "Information systems evaluation: navigating through the problem domain”, Information \& Management, vol. 40, n. 1: 11-24, https://doi.org/10.1016/s0378-7206(01)00128-8.

KALE, V. (2000): "Implementing SAP R/3: The guide for business and technology managers”, Indianápolis: Sams Publishing.

KONSTAŃCZAK S. (2016): „Doskonałość jako problem moralny w pracach Stanisława Tatarkiewicza”, SOFIA. Artykuły teoretyczne i historyczne, vol. 16: 157-176, https://doi.org/10.15584/sofia.2016.16.10.

LIRA, A. M. D., PARISI, C., PELEIAS, I. R., \& PETERS, M. R. S. (2012): "Uses of ERP systems and their influence on controllership functions in Brazilian Companies”, JISTEM-Journal of Information Systems and Technology Management, vol. 9, n. 2: 323-352, https://doi.org/10.4301/s180717752012000200007.

LYYTINEN, K. (1987): “Different perspectives on information systems: problems and solutions”, ACM Computing Surveys (CSUR), vol. 19, n. 1: 5-46, https://doi.org/10.1145/28865.28867.

MŁODKOWSKI, P., KAŁUŻNY, J. (2007): „Próba rozwiązania problemu niedopasowania systemów informacyjnych do wymagań controllingu w przedsiębiorstwie”, [in:] „Narzędzia controllingu w przedsiębiorstwie”, Sierpińska, M., Kustra, A. (eds.), pp. 22-31, VIZJA PRESS\&IT, Warszawa. 
NIU, N., DA XU, L., \& BI, Z. (2013): "Enterprise information systems architecture-Analysis and evaluation”, IEEE Transactions on Industrial Informatics, vol. 9, n. 4: 2147-2154, https://doi.org/10.1109/tii.2013.2238948.

NOWOSIELSKI K. (2011): “Kierunki usprawniania procesów controlling”, [in:] „Podejście procesowe w organizacjach”, Prace Naukowe UE we Wrocławiu, n. 169: 243-254.

NOWOSIELSKI K. (2013): “Controlling Maturity Model 2013”, http://www.controlling.ue.wroc.pl/ 5icomm_pl.html, 2013.

NOWOSIELSKI S. (2001): “Centra kosztów i centra zysku w przedsiębiorstwie”, Wyd. Akademii Ekonomicznej im. Oskara Langego we Wrocławiu, Wrocław.

PALMIUS, J. (2007): “Criteria for measuring and comparing information systems", Proceedings of the 30th Information Systems Research Seminar in Scandinavia IRIS 2007.

PARE, G., TRUDEL, M. C., JAANA, M., \& KITSIOU, S. (2015): “Synthesizing information systems knowledge: A typology of literature reviews”, Information \& Management, vol. 52, n. 2: 183-199, https://doi.org/10.1016/j.im.2014.08.008.

PELEIAS, I. R. \& PARISI, C. (2001): “Contribuições e limitações dos sistemas integrados às funções de controladoria no novo ambiente de negocios”, 13th ed. Asian Pacific Conference on Internacional Accounting Issues. Rio de Janeiro, Brasil.

PELEIAS, I. R., TREVIZOLI, J. C., CORTES, P. L. \& GALEGALE, N. V. (2009): "Pesquisa sobre a percepção dos usuários dos módulos contábil e fiscal de um sistema erp para o setor de transporte rodoviário de cargas e passageiros”, Revista de Gestão da Tecnologia e Sistemas de Informação (Online), n. 6: 247270., https://doi.org/10.4301/s1807-17752009000200006.

SIERPIŃSKA M., NIEDBAŁA B. (2003): “Controlling operacyjny w przedsiębiorstwie”, PWN, Warszawa.

SKRZYNIARZ P. (2002), Indyholidyna - pryzmat controllera, CiRZ, nr 3.

TWOREK, K. (2018a): "Information systems reliability in the context of higher education institutions”, 10th annual International Conference on Education and New Learning Technologies: Conference Proceedings, Palma de Mallorca 
(Spain). 2nd - 4th of July, 2018. IATED Academy., https://doi.org/ 10.21125/edulearn.2018.2231.

TWOREK K. (2018b): "Reliability of information systems in organization in the context of banking sector: empirical study from Poland”, Cogent Business and Management, vol. 5, n. 1, doi 10.1080/23311975.2018.1522752.

VOLLMUTH H.J. (2000): “Controlling. Planowanie, kontrola, zarządzanie”, Placet, Warszawa.

WALECKA-JANKOWSKA K., ZGRZYWA-ZIEMAK A. (2006): “Udział technologii informatycznych w procesach interpretacji i zapamiętywania wiedzy.” [in:] "Sposoby osiągania doskonałości organizacji w warunkach zmienności otoczenia - wyzwania teorii i praktyki” (ed. E. Skrzypek), Wydział Ekonomiczny UMCS, Lublin, vol. 2: 91-99.

WEIßENBERGER, B. E., ANGELKORT, H. (2011): “Integration of financial and management accounting systems: The mediating influence of a consistent financial language on controllership effectiveness”, Management Accounting Research, vol. 22.

ZAHEDI, F. (1987): "Reliability of information systems based on the critical success factors-formulation”, Mis Quarterly, pp. 187-203, https://oi.org/ $10.2307 / 249362$. 